\title{
Phylogenetic of Marble Goby (Oxyeleotris marmorata Blkr.) in South Sumatra Based on Cytochrome C Oxidase Subunit I (COI) Gene
}

\author{
Mochamad Syaifudin ${ }^{1, *}\left(\mathbb{D}\right.$, Dade Jubaedah ${ }^{1}$, Ferdinand Hukama Taqwa ${ }^{1}$, Ria \\ Octaviani $^{1}$
}

${ }^{1}$ Universitas Sriwijaya, Faculty of Agriculture, Program Study of Aquaculture, Jl. Palembang-Prabumulih Km 32, Indralaya, Ogan Ilir 30862, South Sumatra, Indonesia.

\section{How to cite}

Syaifudin, M., Jubaedah, D., Taqwa, F.H., Octaviani, R. (2022). Phylogenetic of Marble Goby (Oxyeleotris marmorata Blkr.) in South Sumatra Based on Cytochrome C Oxidase Subunit I (COI) Gene. Genetics of Aquatic Organisms, 6(1), GA433. http://doi.org/10.4194/GA433

\section{Article History}

Received 03 June 2021

Accepted 18 November 2021

First Online 18 November 2021

\section{Corresponding Author}

Tel.: +6282177933568

E-mail: msyaifudin@fp.unsri.ac.id

\section{Keywords}

Cytochrome C Oxidase Subunit I gene

O. marmorata

Domesticated

PCR

South Sumatra

\begin{abstract}
Marble goby (Oxyeleotris marmorata) in Indonesia, spread across Sumatra, Kalimantan and Papua. The purpose of this study was to utilize a sequence of mitochondrial DNA Cytochrome Oxidase Subunit I gene, to analyze the phylogenetic tree and genetic distance between cultured and captured populations. This research was conducted on March-August 2020. The methods used in barcoding species were DNA isolation, amplification using PCR (Polymerase Chain Reaction) and sequencing of the COI mtDNA gene. The domesticated samples $(n=3)$ were collected from Gandus Fish Seed Center (GFSC), while the wild samples $(n=3)$ were captured from the Musi River in Beruge Village, Babat Toman District, both in Musi Banyuasin Regency. The sequenced COI mtDNA gene fragments were obtained from the PCR method. Three samples performed good PCR results, while the other three didn't amplify properly. After the editing process, the $\mathrm{COI}$ gene sequencing produced a nucleotide length of $610 \mathrm{bp}$. Based on the BLAST (Basic Local Alignment Search Tool), domesticated marble goby (OMD2, OMD3) was in the same cluster with marble goby from the Musi River (OMS3). The genetic distance indicated that two specimens of domesticated marble goby were $100 \%$ identical, while the wild (OMS3) indicated a genetic distance of 0.0066 to domesticated species.
\end{abstract}

\section{Introduction}

The marble goby (Oxyeleotris marmoratus, Bleeker) also known as the sand goby is widely distributed in Southeast Asia, especially in Malaysia, Singapore, Thailand and Vietnam (Cheah, Senoo, Lam, \& Ang, 1994; Mohsin \& Ambak, 1983; Poh, Ving, \& Shaliza, Ibrahim Vikineswary, 2015). It is also one of the indigenous species of freshwater fish in Indonesia. There are 17 species of marble goby, 11 of which are found globally and 8 species are found in Indonesia, which are Oxyeleotris urophthalmoides, $O$. colasi, $O$. wisselensis, $O$. heterodon, 0 . paucipora, 0 . urophthalmus, 0 . marmorata and O. altipinna. Oxyeleotris marmorata, commonly found in the Musi River (Kordi, 2013), is an introduction species from China since 1927 (Food and Agriculture Organization (FAO) of United Nation, 2005; Wargasasmita, 2012), either for ornamental or consumption. It is an important commercial fish because of its good taste, rich nutrition, large size and potential in aquaculture (Zhao et al., 2017). In Indonesia, the species is spread across the water resources of Sumatra, Kalimantan and Papua (Fishbase, 2021). However, the presence of introduced species could threaten the loss of indigenous freshwater species in Sempor Reservoir, Kebumen (Lestari, Rukayah, \& Jamilatun, 2019).

Domestication efforts of marble goby have been carried out at the Mariana Public Aquatic Fisheries Research Institute (BRPPU) and Gandus Fish Seed Center (GFSC), South Sumatra. There are 260 genetic data for 
marble goby, one of them was marble goby from West Java, but none of the genetic data is originated from Sumatra (National Center for Biotechnology Information, 2021).

DNA barcoding is a system designed for precise and accurate identification of a species using a short and standardized gene region (Hebert et al., 2003). Research on DNA Barcode has been carried out on several freshwater fish, including featherbacks (Sodsuk. \& Sodsuk, 2000), Asian Redtail Catfish (Syaifudin et al., 2017), tilapia (Syaifudin et al., 2017), striped snakehead and ocellated snakehead fish (Syaifudin et al., 2020). The most promising benefit of DNA barcoding for species authentication lies in the ability to identify early stages that cannot be done by using morphological descriptions. It has been proved to be effective for identifying species in juvenile and larvae of Lutjanus cyanopterus in Caribbean beach (Victor, Hanner, Shivji, Hyde, \& Caldow, 2009) and 75\% of coral reef fish larvae sampled $(n=373)$ in the Pacific (Hubert, Espiau, Meyer, \& Planes, 2014). Based on NCBI (2019), DNA barcode on marble goby fish has been carried out in Japan, Indonesia (West Java) (Dahruddin, Hadiaty, \& Hubert, 2016), Australia (Ward, Zemlak, Innes, Last, \& Hebert, 2005), China and Thailand (Panprommin, Iamchuen, Soontornprasit, \& Tuncharoen, 2020).

This research is conducted to amplify nucleotide sequences of the COI gene, to identify species, determine genetic distances and analyze phylogenetic relationships of domesticated marble goby from Gandus Fish Seed Centre at Gandus, Palembang in South Sumatra and from the Musi River Banyuasin Regency, as a wild fish habitat in the region. Thus, the identification of the species using the COI gene is an effort to develop genetic information that can be used as the basis for the fish selection process through hybridization activities.

\section{Materials and Methods}

\section{Study Area}

The study was conducted in the Musi River in Beruge Village, Babat Toman District, Musi Banyuasin Regency in South Sumatera, representing a wild habitat of marble goby $(n=3)$; and GFSC Gandus, Palembang Regency, representing a domesticated fish $(n=3)$ (Figure $1)$.

\section{Biological materials}

Six specimens of marble goby were acquired from the wild and domesticated fish. The fishes were captured by local fisherman with approximate size of 0.309-0.326 kg for weight and $30 \mathrm{~cm}$ for length (code of sample OMS1, OMS2 \& OMS3), meanwhile the domesticated fish size were $0.278-0.322 \mathrm{~kg}$ for weight and 21.5-30 cm for length (OMD1, OMD2 \& OMD3). For each specimen, approximately $4 \mathrm{~cm}$ of a segment of the caudal fin was dissected with a sterile blade, then stored in $1.5 \mathrm{ml}$ tubes containing $96 \%$ ethanol, labeled and kept in the freezer at $-20{ }^{\circ} \mathrm{C}$ until DNA extraction.. Domesticated marble goby have been cultured in a rearing pond for a year, fed with live fish such as tilapia and nilem fry and spawned semi naturally at once.

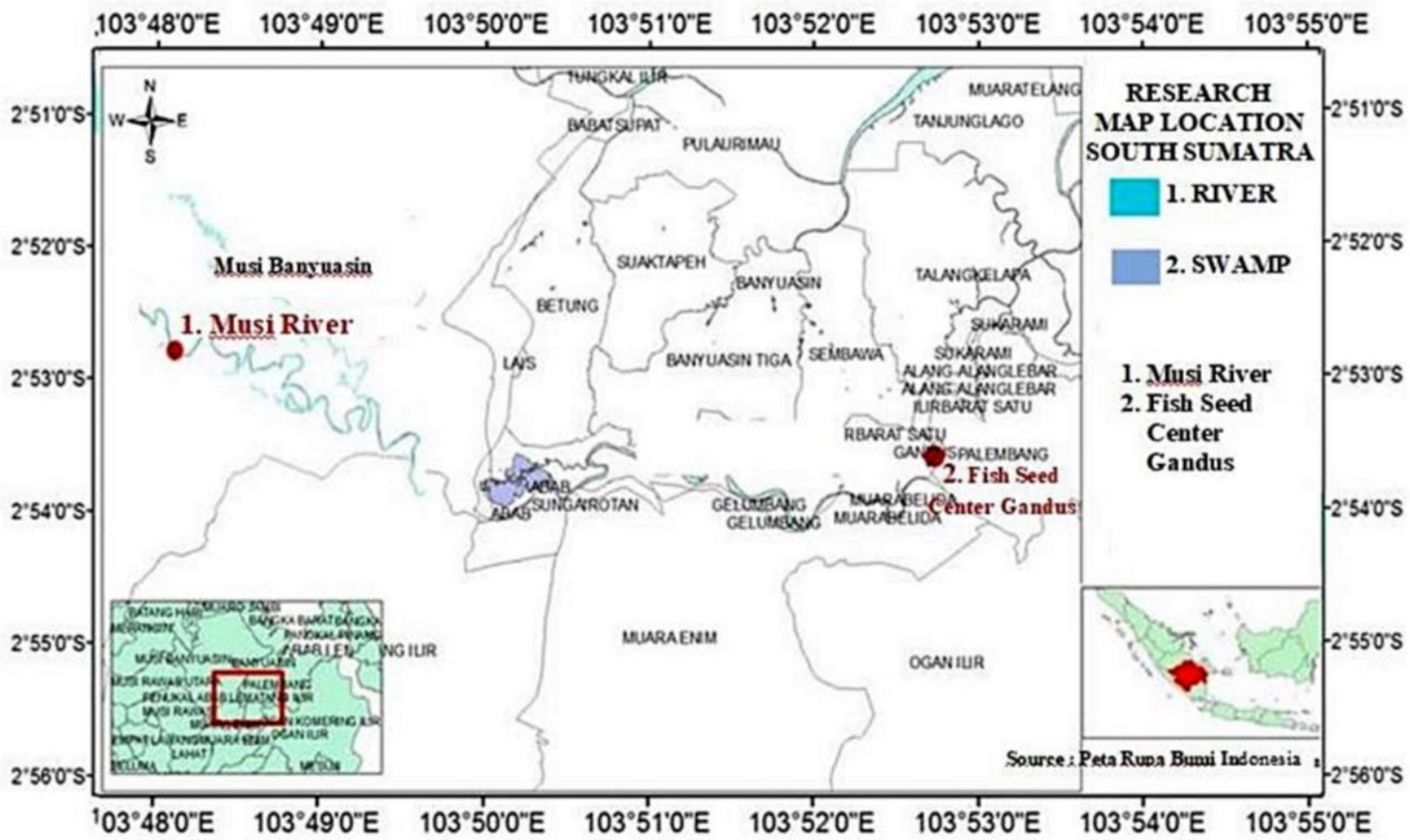

Figure 1. Two sampling site of marble goby from South Sumatra. 1. Musi River; 2. Fish Seed Center Gandus 


\section{DNA Extraction}

DNA was extracted from fin clips of all specimens. Total genomic DNA was extracted using the Realpure Genomic DNA Extraction Kit (Durviz S.L) following the manufacturer's manual. DNA extraction consists of 5 stages including, cell lysis, RNAse treatment, DNA precipitation, washing and dissolution of DNA. Four $\mu \mathrm{l}$ of RNAse were added in the lysis step to minimise RNA contamination. Those samples that passed quality control (no observable RNA) based on DNA band visualization in the gel documentation were selected for used in PCR.

\section{DNA Amplification}

DNA of the four marble goby were used in PCR with primer pairs of FishF25'TCGACTAATCATAAAGATATCGGCAC3' and FishR25'ACTTCAGGGTGACCGAAGAATCAGAA3' to amplify 650 bp fragment (Ward et al., 2005). PCR was performed in a final volume of $50 \mu \mathrm{l}$ using MyTaq ${ }^{\mathrm{TM}}$ Red Mix (Bioline). Each reaction contained $1 \mu \mathrm{l}$ of $10 \mu \mathrm{M}$ each primer (F2 and R2 primers) (Ward et al., 2005), $20 \mu$ of nucleasefree water, $25 \mu \mathrm{l}$ myTaq polymerase red mix and $3 \mu \mathrm{l}$ of DNA template. The thermal cycling protocol was as follows: initial denaturation at $95^{\circ} \mathrm{C}$ for $1 \mathrm{~min}$ ( $1 \mathrm{cycle}$ ) followed by 35 cycles of $95^{\circ} \mathrm{C}$ for $15 \mathrm{sec}$, annealing at $50^{\circ} \mathrm{C}$ for $30 \mathrm{sec}$, extension or elongation at $72^{\circ} \mathrm{C}$ for 15 $\mathrm{sec}$ and a final extension at $72^{\circ} \mathrm{C}$ for $4 \mathrm{~min}$. Furthermore, PCR products were run in electrophoresis $1 \%$ agarose gel at $75 \mathrm{~V}$ for 35 minutes and visualized to determine the DNA bands using Gel Documentation. The size of PCR product was measured using $1 \mathrm{~kb}$ marker. DNA samples that were successfully amplified using PCR were then sequenced in the target area of the COI gene. PCR products were commercially sequenced (Sanger sequencing, GATC Biotech Ltd.) at 1st Base DNA Sequencing Service.

\section{Data Analysis}

Six sequences of COI gene (OMS3, OMD2 and OMD3) from forward 2 and reverse 2 were saved in Fasta format (OMS1, OMS2 and OMD1 were discarded from the analysis due to low quality of PCR product and sequencing result). The sequences were analyzed their identity using BLAST (Basic Local Alignment Search Tool) in NCBI (National Center for Biotechnology Information). For sequence comparisons, pairwise genetic distances were quantified based on the Kimura 2-parameter (K2P) distance model (Kimura, 1980). Voucher sequences from GenBank, and consensus sequences of each samples generated from this study were used to construct phylogenetic tree. The phylogenetic tree of marble goby was constructed using the NeighborJoining (NJ) method on MEGA software $X$ Version (Sudhir Kumar, Stecher, Li, Knyaz, \& Tamura, 2018; Stecher, Knyaz, Tamura, \& Kumar, 2020). Bootstrapping value was carried out in 1000 replications. In the phylogenetic construction, Oreochromis niloticus (KM438538.1) (Syaifudin, Bekaert, et al., 2017) was also added as species outgroup.

\section{Results and Discussion}

\section{Molecular Identification}

The resultant fragments of sequences were approximately 680 - 698 base pairs (bp). After trimming process with MEGA (Molecular Evolutionary Genetics Analysis) version 7 (S. Kumar, Stecher, \& Tamura, 2016), the length of sequences were $610 \mathrm{bp}$ and no gaps within sequences. The BLASTn analysis showed that COI sequences of marble goby in this study accordance with those in the GenBank database. The identity percentage was exhibited in Table 1.

The result of BLASTn analyses in Table 1 denoted that nucleotide sequences of the domesticated fish, OMD2 and OMD3 were identical, showing 99.51\% matched to Oxyeleotris marmorata from Malaysia (KT022088.1) and USA (AY722177.1), meanwhile the wild marble goby (OMS3) indicated highest similarity (100\%) to Oxyeleotris marmorata from Cambodia (EF609424.1), West Java, Indonesia (KU692726.1) and Vietnam (MH721190.1). Sequence similarity higher than $97 \%$ was the criterion for authentication at the species level (Wong \& Hanner, 2008) and a similarity lower than that was used for recognition at the genus level. This result denoted that distinguishing species using DNA barcoding is very accurate. The COI is effectively used as species authentication method because intraspecific

Table 1. Identity percentage of nucleotide of marble goby.

\begin{tabular}{lccc}
\hline No. & \multicolumn{1}{c}{ Species } & Origin & Accession no. \\
\hline \multicolumn{2}{l}{ Samples code: OMD3 and OMD2 } & & \\
\hline 1 & Oxyeleotris marmorata & Malaysia & KT022088.1 \\
2 & Oxyeleotris marmorata & USA & AY722177.1 \\
3 & Oxyeleotris marmorata & Indonesia & KU692726.1 \\
\hline Sample code: OMS3 & & & \\
\hline 1 & Oxyeleotris marmorata & Indonesia & KU692726.1 \\
2 & Oxyeleotris marmorata & Cambodia & EF609424.1 \\
3 & Oxyeleotris marmorata & Vietnam & MH721190.1 \\
\hline
\end{tabular}


variation is low, but has high interspecific variation values especially in adjacent taxa (Ward et al., 2005). DNA barcoding validates to recognize species for international trading, either certifying fisheries products consumption or ornamental fish trade (Dahruddin et al., 2016). It has been successfully authorize species larval stages of marble goby in Thailand for sustainable fishery resource management (Panprommin et al., 2020).

\section{Genetic Distance and Phylogenetic}

Genetic distance at this study was also used to determine the genetic relationship between domesticated (OMD2 and OMD3) and wild stock (OMS3) marble goby in South Sumatra (Table 2). It indicated that two specimens of domesticated marble goby were $100 \%$ identical, while the wild (OMS3) showed a genetic distance of 0.0066 to domesticated species. The domesticated marble goby were also identic to the same species from Malaysia (KT001058.1), while OMS3 was identic to marble of goby from Cambodia (EF609424.1), Thailand (MK448189.1) and West Java, Indonesia (KU692718.1 and KU692726.1). Hebert et al. (2003) stated that a genetic distance difference of less or equal to $3 \%$ indicates molecularly identical species. The smaller the genetic distance between individuals in a population, the more uniform the population is. Conversely, the greater the genetic distance of an individual in a population, the more diverse the population will be. The largest genetic distance (0.2082) was found between $O$. marmorata and species outgroup Oreochromis niloticus from Stirling (KM438538.1), followed to Palatogobius paradoxus (0.1557) from America (MF049134.1). It is clearly denoted that within $O$. marmorata barcode variation was low in compare to the sequence variation between species in genus Oxyeleotris. Genetic distance indicates the ratio of a genetic distinction between species or populations (Dogan, Dogan, \& Nurhan, 2016). Therefore, a smaller genetic distance value creates a more indistinguishable appearance partial sequence of $\mathrm{CO} 1$ gene compared between the two species (Basith, Abinawanto, Kusrini, \& Yasman, 2021).
The phylogenetic tree of marble goby was presented in Figure 2. This study determined the level of evolution and kinship of a species, where the cluster $O$. marmorata was separated from $O$. selheimi (AY722166.1, AY722179.1) and O. lineolata (KJ669574.1, AY722165.1) (bootstrap value/bv of 97\%). Within species, O. marmorata was separated into two subclusters (bv of 68\%). The first sub-cluster consisted of $O$. marmorata from Thailand (MK448189.1, MK448069.1), Malaysia (KT001058.1), Cambodia (EF609424.1), Indonesia (KU692718.1, KU692726.1), Vietnam (MH721190.1) including samples of 0 . marmorata from the Musi River (OMS2, OMS3) and domesticated fish (OMD2, OMD3). The second sub-cluster consists of $O$. marmorata from Thailand (MK628379.1, KF410694.1) and Malaysia (KT022088.1). Meanwhile, O. marmorata from USA (AY722176.1 and AY722177.1 and AY722177.1) made distant subcluster to the same species afore mention.

The second cluster is occupied by species that are still in the same genus of marble goby. There were two species found in the second cluster, i.e. O. selheimi from Los Angeles (America) and O. lineolata (Los Angeles, USA) and $O$. lineolata (Australia). The third cluster was $P$. paradoxus (America), while, the fourth cluster was consisted of $O$. niloticus (Stirling), as an outgroup species. The Oxyeleotris was belong to Butidae family, while Palatogobius was belong to Gobiidae family. A previous study using sequence data of five molecular markers (two mitochondrial and three nuclear) indicated that Butidae being sister group to the Gobiidae clade, to the exclusion of Eleotrididae (Agorreta et al., 2013). A bootstrap value greater than $70 \%$ indicates that the data is relatively stable (Lemey, Selemi, \& Vandamme, 2009). The phylogenetic tree construction resulted in a scale bar of 0.02 . According to Wardani et al. (2017), a phylogenetic tree with a 0.01 scale bar shows a genetic distance with a change in nucleotides 1 time every $100 \mathrm{bp}$. So that the phylogenetic constructs obtained indicate a genetic distance with nucleotide changes 2 times in every $100 \mathrm{bp}$. DNA barcoding technology has been utilized and validated for many aquatic species with detected more variation among

Table 2. Genetic distance between species marble goby based on COI gene.

\begin{tabular}{|c|c|c|c|c|c|c|c|c|c|c|c|c|c|c|c|c|c|c|c|c|c|c|c|}
\hline \multirow{2}{*}{ No. } & \multirow{2}{*}{ Spesies } & \multicolumn{22}{|c|}{ Genetic Distance } \\
\hline & & 1 & 2 & 3 & 4 & 5 & 6 & 7 & 8 & 9 & 10 & 11 & 12 & 13 & 14 & 15 & 16 & 17 & 18 & 19 & 20 & 21 & 22 \\
\hline 1. & O. marmorata_OMD2_(Indonesia)* ${ }^{*}$ & & & & & & & & & & & & & & & & & & & & & & \\
\hline 2. & O. marmorata_OMD3_Gandus_(Indonesia)* & 0.000 & & & & & & & & & & & & & & & & & & & & & \\
\hline 3. & O. marmorata_OMS2_Musi River_(Indonesia)* & 0.000 & 0.000 & & & & & & & & & & & & & & & & & & & & \\
\hline 4. & o. marmorata_OMS3_Musi River_(Indonesia)* & 0.000 & 0.000 & 0.000 & & & & & & & & & & & & & & & & & & & \\
\hline 5. & O. marmorata_Malaysia_KT001058.1 & 0.002 & 0.002 & 0.002 & 0.002 & & & & & & & & & & & & & & & & & & \\
\hline 6. & O. marmorata_Cambodia_EF 609424.1 & 0.002 & 0.002 & 0.002 & 0.002 & 0.000 & & & & & & & & & & & & & & & & & \\
\hline 7. & O. marmorata_Indonesia_KU692718.1 & 002 & 0.002 & 0.002 & 0.002 & 0.000 & 0.000 & & & & & & & & & & & & & & & & \\
\hline 8. & O. marmorata_Thailand_MK448189.1 & .002 & 0.002 & 0.002 & 0.002 & 0.000 & 0.000 & 0.000 & & & & & & & & & & & & & & & \\
\hline 9. & O. marmorata_Indonesia_KU692726.1 & .002 & 0.002 & 0.002 & 0.002 & 0.000 & 0.000 & 0.000 & 0.000 & & & & & & & & & & & & & & \\
\hline 10. & O. marmorata_Malaysia_KT001057.1 & 0.004 & 0.004 & 0.004 & 0.004 & 0.004 & 0.004 & 0.004 & 0.004 & 0.004 & & & & & & & & & & & & & \\
\hline 11. & O. marmorata_Thailand_M & 0.004 & 0.004 & 0.004 & 0.004 & 0.002 & 0.002 & 0.002 & 0.002 & 0.002 & 0.006 & & & & & & & & & & & & \\
\hline 12. & O. marmorata_Vietn & .004 & 0.004 & 0.004 & 0.004 & 0.002 & 0.002 & 0.002 & 0.002 & 0.002 & 0.006 & 0.004 & & & & & & & & & & & \\
\hline 13. & O. marmorata_Los $\mathrm{A}$ & 0.008 & 0.008 & 0.008 & 0.008 & 0.006 & 0.006 & 0.006 & 0.006 & 0.006 & 0.006 & 0.008 & 0.008 & & & & & & & & & & \\
\hline 14. & O. marmorata_USA_AY722 177.1 & .008 & 0.008 & 0.008 & 0.008 & 0.006 & 0.006 & 0.006 & 0.006 & 0.006 & 0.006 & 0.008 & 0.008 & 0.000 & & & & & & & & & \\
\hline 15. & O. marmorata_Malaysia_KT022088.1 & 008 & 0.008 & 0.008 & 0.008 & 0.006 & 0.006 & 0.006 & 0.006 & 0.006 & 0.006 & 0.008 & 0.008 & 0.000 & 0.000 & & & & & & & & \\
\hline 16. & O. marmorata_Thailand_MK628379.1 & 08 & 0.008 & 0.008 & 0.008 & 0.006 & 0.006 & 0.006 & 0.006 & 0.006 & 0.006 & 0.008 & 0.008 & 0.000 & 0.000 & 0.000 & & & & & & & \\
\hline 17. & O. mar & & 0.012 & 0.012 & 0.012 & 0.010 & 0.010 & 0.010 & 0.010 & 0.010 & 0.010 & 0.012 & 0.012 & 0.004 & 0.004 & 0.004 & 0.004 & & & & & & \\
\hline 18. & O. selheimi_Los Ang & 122 & 0.122 & 0.122 & 0.122 & 0.122 & 0.122 & 0.122 & 0.122 & 0.122 & 0.124 & 0.124 & 0.120 & 0.124 & 0.124 & 0.124 & 0.124 & 0.128 & & & & & \\
\hline 19. & O. selheimi_Los Angeles_AY722179.1 & 0.134 & 0.134 & 0.134 & 0.134 & 0.134 & 0.134 & 0.134 & 0.134 & 0.134 & 0.136 & 0.136 & 0.132 & 0.136 & 0.136 & 0.136 & 0.136 & 0.140 & 0.072 & & & & \\
\hline 20. & O. lineolata_Los Ar & 0.134 & 0.134 & 0.134 & 0.134 & 0.134 & 0.134 & 0.134 & 0.134 & 0.134 & 0.136 & 0.136 & 0.132 & 0.136 & 0.136 & 0.136 & 0.136 & 0.140 & 0.072 & 0.000 & & & \\
\hline 21. & O. Ii & 136 & 0.136 & 0.136 & 0.136 & 0.136 & 0.136 & 0.136 & 0.136 & 0.136 & 0.138 & 0.138 & 0.134 & 0.138 & 0.138 & 0.138 & 0.138 & 0.142 & 0.074 & & & & \\
\hline 22. & Palatogobiuls paradoxis_USA_MF049134.1 & 0.167 & 0.167 & 0.167 & 0.167 & 0.167 & 0.167 & 0.167 & 0.167 & 0.167 & 0.163 & 0.167 & 0.165 & 0.165 & 0.165 & 0.165 & 0.165 & 0.169 & 0.181 & 0.196 & 06 & 0.1 & \\
\hline 23. & Oreochromis niloticus Stirling & 0.217 & 0.217 & 0.217 & 0.217 & 0.217 & 0.217 & 0.217 & 0.217 & 0.217 & 0.216 & 0.217 & 0.216 & 0.214 & 0.214 & 0.214 & 0.214 & 0.217 & 0.192 & 0.206 & 0.206 & 0.204 & 83 \\
\hline
\end{tabular}






Figure 2. Phylogenetic tree of marble goby from South Sumatra

congeneric species than among conspecific individual (Ward et al., 2005). Therefore it can effectively used to distinguish a complex of morphologically distinct species in the Indo-Pacific (Last, Manjaji, \& Yearsley, 2005).

\section{Conclusions}

In summary, DNA barcoding have been developed for species authentication for pivotal aquaculture and wild species of marble goby. Thus, the DNA barcodes will support fish products inspection and regulation requirements by establishing correct labeling of domesticated and wild marble goby in the market.

\section{Ethical Statement}

All listed co-authors declare that the present study was conducted in an ethical, professional and responsible manner.

\section{Funding Information}

The authors would like to thank the contribution of the Sriwijaya Univeristy www.unsri.ac.id for Competitive Research Grant (grant reference number
0179.043/UN9/SB3.LPPM.PT/2020) and institutions support towards the research.

\section{Author Contribution}

The conception and design of the study: MSF; the acquisition of data, or the analysis and interpretation: RO, FHT; Funding Acquisition: MSF, writing-original draft: RO, DJ; wrirting-review and editing: MSF, FHT, DJ.

\section{Conflict of Interest}

The author(s) declare that they have no known competing financial or non-financial, professional, or personal conflicts that could have appeared to influence the work reported in this paper.

\section{Acknowledgements}

We are grateful to the Head of Plant Physiology Laboratory (Prof. Dr Ir. Rujito Agus Suwignyo, M. Agr) and Laboratory of Basic Fisheries and their staff for supporting the research at the Faculty of Agriculture Sriwijaya University. 


\section{References}

Agorreta, A., San Mauro, D., Schliewen, U., Van Tassell, J. L., Kovačić, M., Zardoya, R., \& Rüber, L. (2013). Molecular phylogenetics of Gobioidei and phylogenetic placement of European gobies. Molecular Phylogenetics and Evolution, 69(3), 619-633.

https://doi.org/10.1016/j.ympev.2013.07.017

Basith, A., Abinawanto, Kusrini, E., \& Yasman. (2021). Genetic diversity analysis and phylogenetic reconstruction of groupers epinephelus spp. From madura island, indonesia based on partial sequence of co1 gene. Biodiversitas, 22(10), 4282-4290. https://doi.org/10.13057/biodiv/d221020

Cheah, S. H., Senoo, S. Y., Lam, S. Y., \& Ang, K. J. (1994). Aquaculture of a high-value freshwater fish in [Malaysia]: the marble or sand goby (Oxyeleotris marmoratus, Bleeker). Naga. Retrieved from https://search.proquest.com/docview/16308426?accou ntid=27308\%0Ahttp://www.worldfishcenter.org/Naga/ na_2082.pdf

Dahruddin, H., Hadiaty, R. K., \& Hubert, N. (2016). DNA Barcoding: Foundations and Applications for Southeast Asian Freshwater Fishes. Treubia, 43(December), 1-16.

Dogan, i.., Dogan, \& Nurhan. (2016). Genetic Distance Measures: Review. Turkiye Klinikleri Journal of Biostatistics, 8(1), 87-93. https://doi.org/10.5336/biostatic.2015-49517

Fishbase. (2021). Oxyeleotris marmorata Bleeker [online]. Retrieved 29 May 2021, from https: ://www.fishbase.se/summary/Oxyeleotrismarmorata.html

Food and Agriculture Organization (FAO) of United Nation. (2005). International Mechanism for the Control and Responsible Use of Alien Species in Aquatic Ecosystem. Report of an ad hoc Expert Consultaion 27 - 30 August 2003. Xishuangbanna, China.

Hubert, N., Espiau, B., Meyer, C., \& Planes, S. (2014). Identifying the ichthyoplankton of a coral reef using DNA barcodes. Molecular Ecology Resources, 15(1), 57-67.

Kimura, M. (1980). A simple method for estimating evolutionary rate of base substitutions through comparative studies of nucleotide sequences. J Mol Evol, 15, 111-120.

Kumar, S., Stecher, G., \& Tamura, K. (2016). MEGA7: Molecular Evolutionary Genetics Analysis Version 7.0 for Bigger Datasets. Mol Biol Evol, 33, 1870-1874.

Kumar, Sudhir, Stecher, G., Li, M., Knyaz, C., \& Tamura, K. (2018). MEGA X: Molecular Evolutionary Genetics Analysis across computing platforms. Molecular Biology and Evolution, 35, 1547-1549.

Last, P. R., Manjaji, B. M., \& Yearsley, G. K. (2005). Pastinachus solocirostris sp. nov., a new species of Stingray (Elasmobranchii: Myliobatiformes) from the Indo-Malay Archipelago. Zootaxa, 1040, 1-16. https://doi.org/10.11646/zootaxa.1040.1.1

Lemey, P., Selemi, M., \& Vandamme, A. M. (2009). The Phylogenetic Handbook: A Practical Approach to Phylogenetic Analysis and Hypothesis Testing. Cambridge-UK: Cambridge University Press.
Lestari, W., Rukayah, S., \& Jamilatun, T. (2019). Ikan Introduks Oxyeleotris marmorata, Bleeker (1852): Populasi, Laju Exploitasi dan Pengendaliannya di Waduk Sempor, Kebumen. Majalah IImiah Biologi Biosfera, 36(3), 132138. https://doi.org/10.20884/1.mib.2019.36.3.823

Mohsin, A., \& Ambak, A. (1983). Freshwater fishes of Peninsular Malaysia. Serdang, Malaysia: University Pertanian publishing house.

National Center for Biotechnology Information. (2021). Oxyeleotris marmorata Bleeker [online].

Panprommin, D., lamchuen, N., Soontornprasit, K., \& Tuncharoen, S. (2020). The utility of DNA barcoding for the species identification of larval fish in the lower ing river, Thailand. Turkish Journal of Fisheries and Aquatic Sciences, 20(9), 671-679. https://doi.org/10.4194/13032712-v20_9_02

Poh, L. L., Ving, C. C., \& Shaliza, Ibrahim Vikineswary, S. (2015). Manipulating Culture Conditions and Feed Quality to Increase the Survival of Larval Marble Goby Oxyeleotris marmorata. North American Journal of Aquaculture, 77(2). https://doi.org/https://doi.org/10.1080/1522205 5.2014 .987932

Sodsuk., P. K., \& Sodsuk, S. (2000). Genetic diversity of featherback fish in Thailand. Kasetsart Journal (National Sciences), 34, 227-233.

Stecher, G., Knyaz, C., Tamura, K., \& Kumar, S. (2020). Molecular Evolutionary Genetics Analysis (MEGA) for macOS. Molecular Biology and Evolution, 37, 1237-1239.

Syaifudin, M., Bekaert, M., Taggart, J., Hulata, G., D'Cotta, H., Baroiller, J., McAndrew, B. (2017). DNA typing across ten tilapia species using cytochrome $C$ oxidase subunit (COI). Aquaculture, 472(4/1), 125-125.

Syaifudin, M., Jubaedah, D., Muslim, M., \& Daryani, A. (2017). DNA authentication of asian redtail catfish Hemibagrus nemurus from Musi and Penukal River, South Sumatra Indonesia. Genetics of Aquatic Organisms, 1(December), 43-48. https://doi.org/10.4194/2459-1831-v1

Syaifudin, M., Wijayanti, M., Dwinanti, S. H., Muslim, Mahendra, M., \& Marliana, S. (2020). Short Communication: DNA barcodes and phylogenetic of striped snakehead and ocellated snakehead fish from South Sumatra, Indonesia, 21(3), 1227-1235. https://doi.org/10.13057/biodiv/d210350

Victor, B. C., Hanner, R., Shivji, M., Hyde, J., \& Caldow, C. (2009). Identification of the larval and juvenile stages of the Cubera Snapper, Lutjanus cyanopterus, using DNA barcoding. Zootaxa, 36(August), 24-36.

Ward, R. D., Zemlak, T. S., Innes, B. H., Last, P. R., \& Hebert, P. D. N. (2005). DNA barcoding Australia's fish species. Philosophical Transactions of the Royal Society of London. Series B, Biological Sciences, 360(1462), 18471857. https://doi.org/10.1098/rstb.2005.1716

Wargasasmita, S. (2012). Ikan air tawar Sumatera yang terancam punah. Jurnal Iktiologi Indonesia, 2(2), 41-49.

Zhao, C., Zhu, X., Gu, Y., Wang, Q., Li, Z., \& Yin, S. (2017). Population genetic diversity of marble goby (Oxyeleotris marmoratus) inferred from mitochondrial DNA and microsatellite analysis. Journal of Genetics, 96(s1), 6571. https://doi.org/10.1007/s12041-017-0850-3 